\title{
Consumer Responses to Green Marketing in Cambodia
}

\author{
Leaksmy Chhay', Md Manik Mian², Rathny Suy ${ }^{3}$ \\ ${ }^{1}$ School of Economics, IIC University of Technology, Phnom Penh, Cambodia \\ ${ }^{2}$ School of Urban Construction and Environmental Engineering, Chongqing University, Chongqing, China \\ ${ }^{3}$ School of Public Affairs, University of Science and Technology of China, Hefei, China \\ Email: manikmbstu@gmail.com
}

Received 16 September 2015; accepted 20 October 2015; published 23 October 2015

Copyright (C) 2015 by authors and Scientific Research Publishing Inc.

This work is licensed under the Creative Commons Attribution International License (CC BY).

http://creativecommons.org/licenses/by/4.0/

cc) (i) Open Access

\begin{abstract}
This study tries to examine the relationship between consumers' socio-economic factors and their willingness to pay more for environmental friendly products, and find the percentages that consumers are agreed to pay for green marketing. Statically analysis revealed that the consumers socioeconomic factors, sex $(* \mathrm{P}<0.05)$, age $\left({ }^{*} \mathrm{P}<0.05\right)$, education $(* * \mathrm{P}<0.01)$, awareness $(* * \mathrm{P}<0.01)$ and monthly income $(* * P<0.01)$ had a significant relationship with their willingness to pay more for environmental friendly products. Among the environmental concern consumers, the percentage of their paying for green products is decreasing with the increasing of product price. A total of $\mathbf{4 3 . 8 9 \%}$ respondents were agreed to pay more for green marketing, and consumers' general suggestion mentioned that the producer pay responsibility, government incentives, public awareness and extensive advertisement of green products were required for the improvement of green marketing in Cambodia.
\end{abstract}

\section{Keywords}

Consumer Responses, Green Marketing, Socio-Economic Factors, Product Price, Willingness to Pay

\section{Introduction}

The concept of "Green Marketing" comes into focus from a major societal concern of environmental degradation. Nowadays, green products, eco-friendly products or green marketing has become an emerging topic of marketing research. People are concentrated on environmental protection from the negative effects of product consumption, manufacturing, and increasing waste byproducts. Recently, a large portion of consumers have shown their interest in purchasing environmental friendly products. Consumers of green products strongly be- 
lieve that the current environment is going to worsen day by day and that the world is facing a grave security problem. Moreover, the non green consumers also realize that the environmental problems will resolve themselves. Hence, consumer's perceptions of environmental problems perhaps influence themselves to pay more for green products [1]. The most reliable evidence of customer attitudes towards green marketing is their interest to pay more for environmental friendly products. In USA, 67 percent of people affirmed that they were willing to pay 5 - 10 percent more for eco-friendly products in 1989 [2], and by 1991, willingness to pay climbed to 15 20 percent by environmentally conscious consumers [3]. A previous study indicates that the environmental concerned customer prefers to buy a green product because of its eco-friendly brand image [4]. Pickett-Baker and Ozaki [5] suggested that companies should supply environmental safe products for their reputation.

Consumption of goods is obvious and it is increasing due to rapid increasing of population, urbanization and economic growth. The increasing products have a negative impact on environment during manufacturing, utilizing and final waste byproducts. Using environmental friendly products is a very significant way to ensure environmental sustainability. During the last two decades, green marketing research has been increasing in many countries, especially in developed countries and developing countries (e.g. China).

The Kingdom of Cambodia is a developing Southeast Asian country, where the concept of green marketing is a new topic of research. The industrial air pollution, water pollution and municipal solid waste management problems are very common in Cambodia. It is very important to study the consumer attitude on green marketing, primarily identifying which customers are willing to pay for environmental friendly products and formulate strategies to enhance green marketing as well as environmental sustainability.

The purposes of this study are:

1) To examine the relationship between consumers' socio-economic factors and their willingness to pay for green marketing;

2) To find the amount of percentages that is willing to pay by environmentally concerned individuals.

\section{Review of Literature}

Environmental friendly marketing is generally known as Green marketing, which is related to entire activities of marketing designed to produce and support any exchange intended to satisfy human needs or wants with a minimal environmental effects [6] [7]. According to American Marketing Association, marketing of products that are supposed to be environmentally safe is called as Green Marketing. The activities encompass under green marketing are considered of the environmental impacts during product manufacturing, packaging, storing, using and final byproduct management. The tendency of green marketing is one of the major strategies of modern business [8]-[10] and consumers around the world are showing their interest in environmentally green products or eco-friendly products. However, there is no exact accepted definition were found to define green products, but previous studies classify green products in several ways. A product is called to be green while that is typically non toxic, non hazardous, originally grown, recyclable or reusable, intact from animal interference, minimally packaged, natural ingredient contents, approved environmentally friendly chemicals [11] [12] and purchasing and consuming is safe for individuals and the environment. According to Mainiery [13], ecological friendly products are environmentally safe products which can facilitate the long term goal of protection and conservation of natural habitat. Bhatia and Jain [14] listed some common characteristics of green products, which are energy efficient (both in use and in production), water efficient (both in use and in production), low emitting (low on hazardous emissions), safe and/or healthy products, recyclable and/or with recycled content, durable (long-lasting), biodegradable, renewable, reused products, third party certified for public or transport standard (e.g., organic, certified wood), locally produced. The green consumers or environmentally conscious individuals [15] are the consumers who avoid any products which might harm or damage to the peoples or the environment during manufacturing, purchasing and consuming [16]. Shrum et al. [17] state that the consumers who's' purchasing behavior is influenced by environmental concern are known as a green consumer.

The first book entitles "Ecological Marketing" was the results of the workshop on Ecological Marketing held by American Marketing Association (AMA) in 1975. Later in the late 1980s and early 1990, green marketing become a prominent concept of marketing, there has been extensive growth of interest in green marketing were shown by marketing academics and practitioners [18] [19]. It was speculated that the organization has moral responsibilities to the society in an eco-friendly way [20]-[23]. Ottman suggested from an organizational viewpoint, the entire activities of marketing should integrate with environmental consideration, including new prod- 
ucts development and communications [24]. The environmental issues of product marketing should not be compromised to satisfy primary customer needs.

A previous survey suggests that 87 percent people of different nations like Brazil, Canada, China, France, Germany, India, the UK and the US have shown their interest in reducing environmental impact [25]. The London government congestion charges are aimed to enhance green products and issues. Though, a variety of research conducted all over the world, but a limited research in consumers' attitude on green marketing was carried out in developing countries [14]. According to the National geographic Society and the international polling firm Globescan survey, developing countries like China, Brazil and India shows higher environmental friendlier attitude than developed countries [26]. IPSOS MORI, interviewed 16,823 consumers in 15 countries to examine consumers and workers, environmental attitudes and behavior (Figure 1), and it can be found that Chinese workers and consumer show more environmental friendly attitudes [27].

Though many consumers show high environmental positive attitudes, but many researchers find very low correlation between consumer attitudes and green behavior [13] [28]. Davidson et al. state that, consumers' attitudes are related to their knowledge and experienced they possess [29], and Juwaheer believe that consumers are considerably aware about green products, but implementing green marketing practice in business is not an easy task [30]. However, Antonio et al. suggested that the environmental consciousness will develop over time, studies on green marketing can identify the consumer attitudes, behaviors and intentions. Laroche et al. research finding indicates that the number of individuals who are willing to pay more for environmentally friendly products is increasing gradually [31].

\section{Methodology}

A close ended questionnaire survey was made to explore the relationship between consumers' socio-economic factors and their willingness to pay more for environmentally friendly products, and how much they want to pay for a different product price.

The respondents were selected randomly from two major provinces (Phnom Penh and Prusat) of Cambodia. A total of 360 respondents were interviewed from 9 large and small markets (phsarchas, central market, Orussey market, BoeungKeng market, The Russian market from Phnom Penh and Prusat new market, Krakor market, Kravanh market, Trapeang Chong market from Prusat province), some schools, and household residence areas. Study data were collected from February 2015 to June 2015.

Respondents' age, sex, marital status, family members, education, occupation and monthly income information were collected to obtain socio-economical status. Five technical questions about recycling sign, recyclable materials, causes of air pollution, water pollution and ozon depletion were asked to examine respondents' knowledge about environmental awareness. To obtain the percentage of their willingness to pay more, environmental conscious consumers was asked about how much they will pay more for a $1 \$, 10 \$, 100 \$$ and $1000 \$$ price of

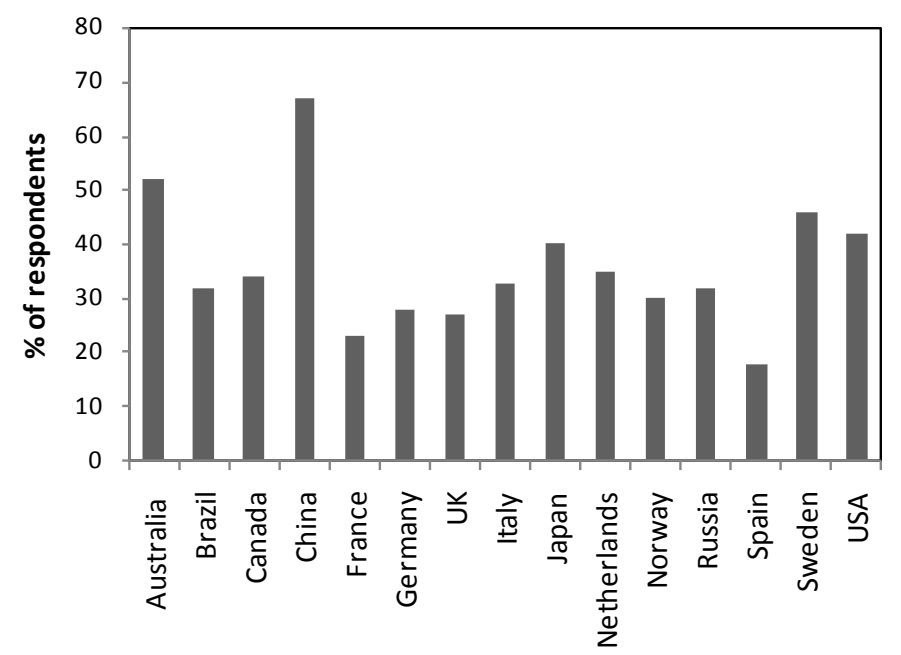

Figure 1. Percentages of consumers and workers showing environmentally friendly attitude. 
product and a general suggestion were taken from all respondents about how to improve green marketing practice in Cambodia, the questionnaire is followed by previous research study [31] and with addition of some other new questions.

Chi square test was used to analyze the relationship between consumers' socio-economic factors and their willingness to pay more for environmental friendly products, Entire survey data were analyzed by using SPSS 2012 and MS excel 2010.

\section{Result and Discussion}

\subsection{Socio-Economic Factors and Green Marketing}

A crosstab analysis was conducted between respondents' socio-economic factors and their willingness to pay for green marketing. The results of statically analysis are illustrated in Tables 1(a)-(h).

The gender of the respondents has a significant relationship with their willingness to pay for green marketing $(* \mathrm{P}<0.05)$, the female individuals were willing to pay more than male individuals, $49.4 \%$ female were willing to pay more for environmental friendly products, whereas male respondents were $38.7 \%$. Previous studies also found the similar relationship between consumers' gender and their willingness to pay for environmental friendly products [31] [32].

The factor "respondents age" followed the similar significant $(* \mathrm{P}<0.05)$ relationship like respondent's gender, the younger consumers were more willing to pay for green products than adult consumers. Earlier research findings show the similarities relationship with respondent age and their willingness to pay for environmental friendly products, though, some researcher find the opposite relationship, the adult consumer are more willing to pay than the younger consumer for green marketing [33] [34].

The education $(* * \mathrm{P}<0.01)$, awareness $(* * \mathrm{P}<0.01)$ and monthly income $(* * \mathrm{P}<0.01)$ of respondents had a highly significant relationship with their willingness to pay for green marketing. Higher educated respondents wanted to pay more for green marketing, $75.7 \%$ and $45.5 \%$ respondents of university and high school, respectively willing to pay for environmental friendly products, whereas $71.6 \%$ and $66.4 \%$ respondents of primary and secondary school respectively didn't agree to pay for green marketing. Perhaps the higher educated people have the higher sensitivity of social problems and environmental issues; they are more likely to contribute to the improvements of social as well as environmental problems. Henion research study finds the similar findings between education and respondent's attitude [35].

The awareness of respondents is technically difference with respondents' education. Generally the educated person is more conscious than the lower educated or illiterate persons. Though, Sandahl and Robertson found that the environmentally conscious consumer is less educated than the average educated American [34]. This study found a very significant relationship between consumers, environmental awareness and their willingness to pay more, respondents who's having a fair and technical idea about environmental pollution and recycling $80 \%$ and $100 \%$ of them respectively were willing to pay for environmental friendly products, whereas $82.4 \%$ unaware and $53.8 \%$ of limited environmental aware respondents were not agreed with green marketing. However, the technical environmentally conscious respondents were very small in number $(N=7)$. The majority of the respondents only considered the direct negative impacts of products into the environment, excluding the effects of products manufacturing. But the meaning of environmental friendly products is;

"Environmentally friendly products are the products, which have no negative impacts into the human beings and the environment during the entire lifecycle of the products".

From the generation to final disposal of the products should be free from negative impacts towards environment. The environmental consciousness of consumers, encourages them to contribute for environmental development, as a result, they are willing to pay more for environmental protection. The previous study's findings of consumers, environmental awareness and willingness to pay are supporting this research finding [1] [36] [37].

The monthly income of respondents is also highly significant $(\mathrm{P}<0.01)$ with respondent's willingness to pay for environmental friendly products. $80 \%, 60.9 \%$ and $73.7 \%$ respondents of (501 $\$$ to up), (401 \$ - 500\$) and (301\$ - $400 \$$ ) monthly income, respectively wanted to pay more for environmental friendly products, whereas $77.9 \%, 48.5 \%$ and $55.8 \%$ respondents of $(0 \$$ to $100 \$),(101 \$-200 \$)$ and $(201 \$-300 \$)$ monthly income were not agreed to pay. People of lower monthly income are mostly disagreed to pay extra cost, perhaps medium and higher monthly income is comparatively easy to support green marketing [35] and lower monthly income is not sufficient to support extra cost for purchasing a products. However in many developed countries, 
Table 1. (a) Relationship between respondents' gender and their willingness to pay for green marketing; (b) Relationship between respondents' age and their willingness to pay for green marketing; (c) Relationship between respondents' marital status and their willingness to pay for green marketing; (d) Relationship between respondents' family member and their willingness to pay for green marketing; (e) Relationship between respondents' education and their willingness to pay for green marketing; (f) Relationship between respondents' awareness and their willingness to pay for green marketing; (g) Relationship between respondents' occupation and their willingness to pay for green marketing; (h) Relationship between respondents' monthly income and their willingness to pay for green marketing.

(a)

\begin{tabular}{ccccc}
\hline & \multicolumn{2}{c}{ Willing to pay more } & \multicolumn{2}{c}{ Not willing to pay more } \\
\hline Respondents' sex & Frequency & Percentage & Frequency & Percentage \\
\hline Male & 72 & 38.7 & 114 & 61.3 \\
Female & 86 & 49.4 & 88 & 50.6 \\
Total & 158 & 43.9 & 202 & 56.1 \\
& & $\mathrm{X}^{2}(1, \mathrm{~N}=360)=4.19, \mathrm{P}<0.05$ & \\
\hline
\end{tabular}

(b)

\begin{tabular}{ccccc}
\hline & \multicolumn{2}{c}{ Willing to pay more } & \multicolumn{2}{c}{ Not willing to pay more } \\
\hline Respondents' age & Frequency & Percentage & Frequency & Percentage \\
\hline $14-20$ & 14 & 34.1 & 27 & 65.9 \\
$21-27$ & 37 & 52.1 & 34 & 47.9 \\
$28-34$ & 39 & 53.4 & 34 & 46.6 \\
$35-41$ & 36 & 46.8 & 41 & 53.2 \\
$42-48$ & 15 & 31.3 & 33 & 68.7 \\
$49-55$ & 17 & 34.0 & 33 & 66.0 \\
Total & 158 & 43.9 & 202 & 56.1 \\
\hline
\end{tabular}

(c)

\begin{tabular}{ccccc}
\hline & \multicolumn{2}{c}{ Willing to pay more } & \multicolumn{2}{c}{ Not willing to pay more } \\
\hline Respondents' marital status & Frequency & Percentage & Frequency & Percentage \\
\hline Married & 78 & 43.6 & 101 & 56.4 \\
Unmarried & 76 & 44.2 & 96 & 55.8 \\
Divorced & 4 & 44.4 & 5 & 55.6 \\
Total & 158 & 43.9 & $\mathrm{X}^{2}(2, \mathrm{~N}=360)=0.01, \mathrm{P}=0.99$ & 56.1 \\
\end{tabular}

(d)

\begin{tabular}{ccccc}
\hline & \multicolumn{2}{c}{ Willing to pay more } & \multicolumn{2}{c}{ Not willing to pay more } \\
\hline Respondents' family member & Frequency & Percentage & Frequency & Percentage \\
\hline $2-4$ & 21 & 39.6 & 32 & 60.4 \\
$5-7$ & 88 & 48.9 & 92 & 51.1 \\
$8-10$ & 49 & 38.6 & 78 & 61.4 \\
Total & 151 & 43.9 & 202 & 56.1 \\
& & $\mathrm{X}^{2}(2, \mathrm{~N}=360)=3.67, \mathrm{P}=0.16$ & \\
\hline
\end{tabular}


(e)

\begin{tabular}{ccccc}
\hline & \multicolumn{2}{c}{ Willing to pay more } & \multicolumn{2}{c}{ Not willing to pay more } \\
\hline Respondents' education & Frequency & Percentage & Frequency & Percentage \\
\hline Primary & 23 & 28.4 & 58 & 71.6 \\
Secondary & 37 & 33.6 & 73 & 66.4 \\
High school & 45 & 45.5 & 54 & 54.5 \\
University & 53 & 75.7 & 17 & 24.3 \\
Total & 158 & 43.9 & 202 & 56.1 \\
\end{tabular}

(f)

\begin{tabular}{ccccc}
\hline & \multicolumn{2}{c}{ Willing to pay more } & \multicolumn{2}{c}{ Not willing to pay more } \\
\hline Respondents' awareness & Frequency & Percentage & Frequency & Percentage \\
\hline No idea & 12 & 17.6 & 56 & 82.4 \\
Limited idea & 67 & 46.2 & 78 & 53.8 \\
Some basic idea & 48 & 43.6 & 62 & 56.4 \\
Fair idea & 24 & 80.0 & 6 & 20.0 \\
Technical idea & 7 & 100 & 0 & 0 \\
Total & 158 & 43.9 & 202 & 56.1 \\
\end{tabular}

(g)

\begin{tabular}{ccccc}
\hline & \multicolumn{2}{c}{ Willing to pay more } & \multicolumn{2}{c}{ Not willing to pay more } \\
\hline Respondents' occupation & Frequency & Percentage & Frequency & Percentage \\
\hline Job & 34 & 40 & 51 & 60 \\
Retired & 31 & 43.1 & 41 & 56.9 \\
Business & 23 & 43.4 & 30 & 56.6 \\
Housewife & 17 & 65.4 & 9 & 34.6 \\
Student & 24 & 42.9 & 32 & 57.1 \\
Unemployed & 29 & 42.6 & 39 & 57.4 \\
Total & 158 & 43.9 & 202 & 56.1 \\
\hline
\end{tabular}

(h)

\begin{tabular}{ccccc}
\hline \multirow{2}{*}{ Respondents' monthly income } & \multicolumn{2}{c}{ Willing to pay more } & \multicolumn{2}{c}{ Not willing to pay more } \\
\hline $0-100 \$$ & Frequency & Percentage & Frequency & Percentage \\
$101-200 \$$ & 25 & 22.1 & 88 & 77.9 \\
$201-300 \$$ & 51 & 51.5 & 48 & 48.5 \\
$301-400 \$$ & 38 & 44.2 & 48 & 55.8 \\
$401-500 \$$ & 14 & 73.7 & 9 & 26.3 \\
$501-$ up \$ & 14 & 60.9 & 4 & 39.1 \\
Total & 16 & 80 & 202 & 20 \\
& 158 & 43.9 & $\mathrm{X}^{2}(5, \mathrm{~N}=360)=19.78, \mathrm{P}<0.01$ & 56.1 \\
\hline
\end{tabular}


there is no significant relationship can be found between consumer monthly income and their willingness to pay for green marketing [31]. Probably, the consumers of developed countries have sufficient monthly income to support extra cost for green marketing. The average monthly wages, and living security of low income individuals in Cambodia is affecting their unwilling to paying more for environmentally friendly products.

The marital status $(\mathrm{P}=0.99)$ (Table $1(\mathrm{c}))$, family members $(\mathrm{P}=0.16)$ (Table $1(\mathrm{~d}))$ and occupations $(\mathrm{P}=0.36)$ (Table $1(\mathrm{~g})$ ) of respondents don't have any significant relation to their willingness to pay more for environmental friendly products.

\subsection{Scope of Green Marketing}

Among 360 consumers of Phnom Penh and Prusat province of Cambodia, 43.89\% of respondents were agreed to pay more for environmentally friendly products and $56.11 \%$ were not. The respondents who are willing to pay more for green marketing are categorized as green consumers. Among the green consumers, the percentage of paying and the price of products are important factors to determine how much the environmentally conscious individual wants to pay for green marketing in Cambodia. It was observed that the percentage of paying for environmental friendly products is decreasing with the increasing of product price (Figure 2). A products of 1 $\$$ price, consumers agreed to pay an average of $0.14 \$$ more for green marketing, whereas a product of $10 \$, 100$ $\$$ and $1000 \$$ they agreed to pay an average of $0.96 \$, 5.37 \$$ and 26.21 \$ more respectively.

However, previous studies indicate a fixed percentage of willingness to pay for environmental friendly products, but indeed the willingness to pay is fluctuating with the product price in Cambodia. Some research findings state that the consumers are usually less likely to purchase green products while they are more expensive [38] [39].

To improve green marketing, respondents' suggestions were taken to enhance green marketing in Cambodia (Table 2). The majority of the respondents (30\%) mention that paying for green products is producer responsi-

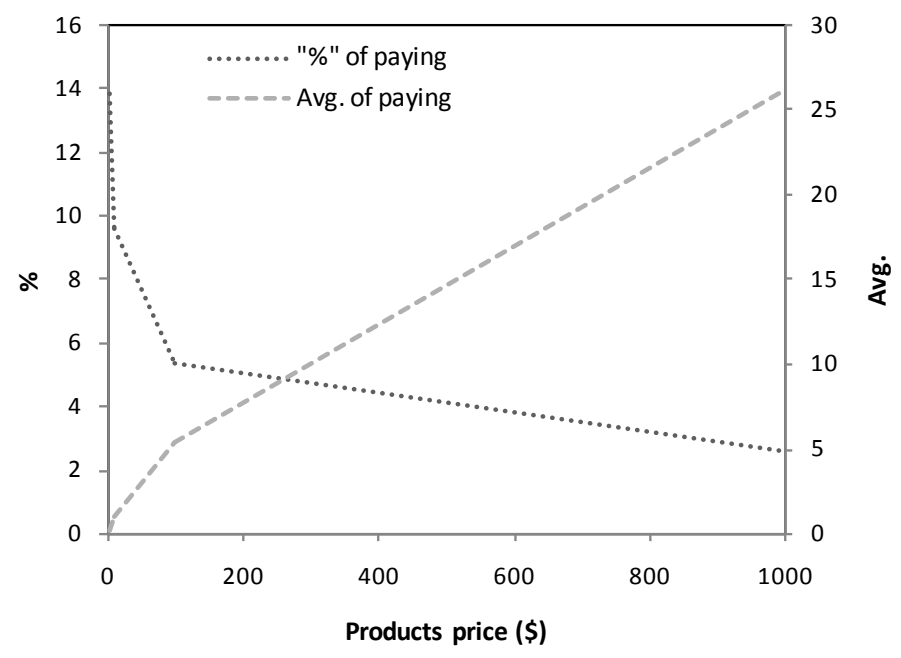

Figure 2. Relationship between percentage of paying for green marketing and product price.

Table 2. Consumers' perception about improvement of green marketing.

\begin{tabular}{cccc}
\hline Consumers perceptions & N & Ranking & 30 \\
\hline Producer pay responsibility & 108 & 23.1 & 2 \\
Don't know/no ideas & 83 & 22.5 & 3 \\
Increase public awareness & 81 & 15.5 & 4 \\
Government incentives/government responsibilities & 56 & 8.9 & 5 \\
\hline
\end{tabular}


bility, the industries who release a produce, they should care about environmental impacts of their products. A large portion of consumers (23.1\%) has no idea about the development of green marketing. However, consumers also recommend the requirements of public awareness about environmental effects of products, government incentives and extensive advertizing of green marketing issues.

According to majority consumers opinion, impose producer responsibility is an effective way to enhance green marketing in Cambodia, however many countries following these strategies to reduce the harmful effects of hazardous products to the environment, but increasing product price has always been a questionable to the consumers. The extensive advertising and awareness of the consumers about green products, its advantages and long term effects on the environment, could possible to create a positive attitude towards green marketing.

\section{Conclusion}

The consumers' response of green marketing in Phnom Penh and Prusat Province of Cambodia was successfully investigated. The socio-economic factors sex, age, education, environmental awareness and monthly income of consumers have a significant relationship with their willingness to pay more for environmental friendly products as well as green marketing. The price of the products influences the willingness to pay by environmentally conscious individuals; the percentage of paying decreases with the increase of product price. The majority of consumers suggest that the charges for the green marketing should be given by the producer organization or government, and that increasing awareness and mass advertisement should be required to increase consumers' positive attitudes towards green marketing.

\section{References}

[1] Banerjee, B. and McKeage, K. (1994) How Green Is My Value: Exploring the Relationship between Environmentalism and Materialism. In: Allen, C.T. and John, D.R., Eds., Advances in Consumer Research, Association for Consumer Research, Provo, 147-152.

[2] Coddington, W. (1990) It's No Fad: Environmentalism Is Now a Fact of Corporate Life. Marketing News, 15 October, 7.

[3] Suchard, H.T. and Polonski, M.J. (1991) A Theory of Environmental Buyer Behaviour and Its Validity: The Environmental Action-Behaviour Model. In: Gilly, M.C., et al., Eds., AMA Summer Educators' Conference Proceedings, American Marketing Association, Chicago, 187-201.

[4] Suki, N.M. (2013) Green Awareness Effects on Consumers' Purchasing Decision: Some Insights From Malaysia. IJAPS, 9, 49-63.

[5] Pickett-Baker, J. and Ozaki, R. (2008) Pro-Environmental Products: Marketing Influence on Consumer Purchase Decision. Journal of Consumer Marketing, 25, 281-293. http://dx.doi.org/10.1108/07363760810890516

[6] Polonsky, M.J. (1994) An Introduction to Green Marketing. Electronic Green Journal, 1, 2-3.

[7] Polonsky, M.J. (2011) Transformative Green Marketing: Impediments and Opportunities. Journal of Business Research, 64, 1311-1319. http://dx.doi.org/10.1016/j.jbusres.2011.01.016

[8] Kassaye, W.W. (2001) Green Dilemma. Marketing Intelligence \& Planning, 19, 444-455. http://dx.doi.org/10.1108/EUM0000000006112

[9] McDaniel, S. and Rylander, D. (1993) Strategic Green Marketing. Journal of Consumer Marketing, 10, 4-10. http://dx.doi.org/10.1108/07363769310041929

[10] Pujari, D. and Wright, G. (1996) Developing Environmentally-Conscious Product Strategy: A Qualitative Study of Selected Companies in Britain and Germany. Marketing Intelligence and Planning, 14, 19-28. http://dx.doi.org/10.1108/02634509610106205

[11] Ottman, J.A. (1993) Green Marketing: Challenges and Opportunities. NTC Business Books, Chicago.

[12] Pavan, M.P.S. (2010) Green Marketing in India: Emerging Opportunities and Challenges. Journal of Engineering, Science and Management Education, 3, 9-14.

[13] Mainiery, T., Barnett, E.G., Valdera, T.R., Unipan, J.B. and Oskamp, S. (1997) Green Buying: The Influence of Environmental Concern on Consumer Behavior. Journal of Social Psychology, 137, 189-204. http://dx.doi.org/10.1080/00224549709595430

[14] Bhatia, M. and Jain, A. (2013) Green Marketing: A Study of Consumer Perception and Preferences in India. Electronic Green Journal, 1, 1-19.

[15] Henion, K.E. and Kinnear, T.C. (1976) Ecological Marketing. American Marketing Association, Chicago. 
[16] Elkington, J. (1994) Toward the Sustainable Corporation: Win-Win-Win Business Strategies for Sustainable Development. California Management Review, 36, 90-100. http://dx.doi.org/10.2307/41165746

[17] Shrum, L., McCarty, J. and Lowrey, T. (1995) Buyer Characteristics of the Green Consumer and Their Implications for Advertising Strategy. Journal of Advertising, 24, 71-82. http://dx.doi.org/10.1080/00913367.1995.10673477

[18] Chamorro, A., Rubio, S. and Miranda, F.J. (2009) Characteristics of Research on Green Marketing. Business Strategy and the Environment, 18, 223-239. http://dx.doi.org/10.1002/bse.571

[19] Bhattacharya, S. (2011) Consumer Attitude towards Green Marketing in India. The IUP Journal of Marketing Management, X, 62-70.

[20] Davis, J.J. (1992) Ethics and Environmental Marketing. Journal of Business Ethics, 11, 81-87. http://dx.doi.org/10.1007/BF00872314

[21] Freeman, R.E. and Liedtka, J. (1991) Corporate Social Responsibility: A Critical Approach. Business Horizons, 34, 92-98. http://dx.doi.org/10.1016/0007-6813(91)90012-K

[22] Keller, G.M. (1987) Industry and the Environment: Toward a New Philosophy. Vital Speeches, 54, 154-157.

[23] Shearer, J.W. (1990) Business and the New Environmental Imperative. Business Quarterly, 54, 48-52.

[24] Ottman, J.A. (1998) Green Marketing: Opportunity for Innovation. NTC-McGraw-Hill, New York.

[25] Mckinsey (2007) Mckinsey and Company Inc., New York.

[26] National Geographic and GlobeScan (2012) Greendex 2012: Consumer Choice and the Environment-A Worldwide Tracking Survey.

[27] IPSOS MORI (2007) Corporate Environmental Behaviour and the Impact on Brand Values. TANDBERG, P-6.

[28] Tracy, A.P. and Oskamp, S. (1984) Relationships among Ecologically Responsible Behaviors. Journal of Environmental Systems, 13, 115-126. http://dx.doi.org/10.2190/6TN8-48WT-63XT-CHEN

[29] Davidson, A.R., Yantis, S., Norwood, M. and Montano, D.E. (1985) Amount of Information about the Attitude Object and Attitude Behavior Consistency. Journal of Personality and Social Psychology, 49, 1184-1198. http://dx.doi.org/10.1037/0022-3514.49.5.1184

[30] Juwaheer, T.D. (2005) Emerging Shades of Green Marketing Conscience among the Population of a Small Island Economy-A Case Study on Mauritius.

[31] Laroche, M., Bergeron, J. and Babaro-Forleo, G. (2001) Targeting Consumers Who Are Willing to Pay More for Environmentally Friendly Products. Journal of Consumer Marketing, 18, 503-520. http://dx.doi.org/10.1108/EUM0000000006155

[32] Myburgh-Louw, J. and O'Shaughnessy, N.J. (1994) Consumer Perception of Misleading and Deceptive Claims on the Packaging of "Green" Fast Moving Consumer Goods. In: Achrol, R. and Mitchell, A., Eds., AMA Summer Educators' Conference Proceedings, Vol. 5, American Marketing Association, Chicago, 344-353.

[33] Van Liere, K.D. and Dunlap, R.E. (1981) The Social Bases of Environmental Concern: A Review of Hypotheses, Explanations and Empirical Evidence. Public Opinion Quarterly, 44, 181-197. http://dx.doi.org/10.1086/268583

[34] Sandahl, D.M. and Robertson, R. (1989) Social Determinants of Environmental Concern: Specification and Test of the Model. Environment and Behavior, 21, 57-81. http://dx.doi.org/10.1177/0013916589211004

[35] Henion, K.E. (1972) The Effect of Ecologically Relevant Information on Detergent Sales. Journal of Marketing Research, 9, 10-14. http://dx.doi.org/10.2307/3149598

[36] Amyx, D.A., DeJong, P.F., Lin, X.H., Chakraborty, G. and Wiener, J.L. (1994) Influencers of Purchase Intentions for Ecologically Safe Products: An Exploratory Study. In: Park, C.W. and Smith, D.L., Eds., AMA Winter Educators' Conference Proceedings, Vol. 5, American Marketing Association, Chicago, 341-347.

[37] Braimah, M. and Tweneboah-Koduah, E.H. (2011) An Exploratory Study of the Impact of Green Brand Awareness on Consumer Purchase Decision in Ghana. Journal of Marketing Development and Competitiveness, 5, 11-18.

[38] Blend, J.R. and Van Ravenswaay, E.O. (1999) Measuring Consumer Demand for Ecolabeled Apples. American Journal of Agriculture Economics, 81, 1072-1077. http://dx.doi.org/10.2307/1244086

[39] D'Souza, C. and Taghian, M. (2006) Green Products and Corporate Strategy: An Empirical Investigation. Society and Business Review, 1, 144-157. http://dx.doi.org/10.1108/17465680610669825 